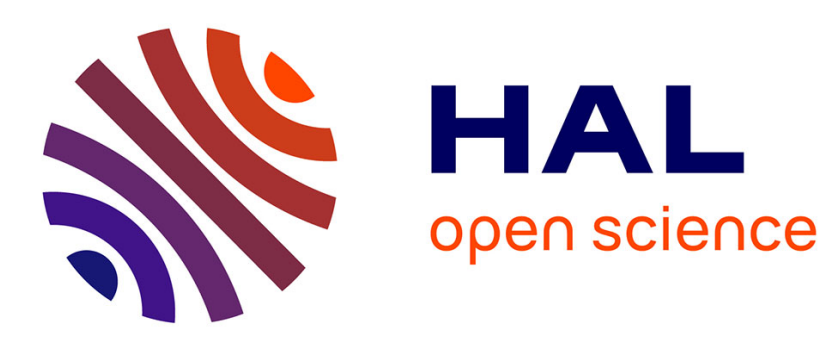

\title{
Citizen participation, an essential lever for urban transformation in France?
}

Camille Gardesse, Jodelle Zetlaoui-Leger

\section{To cite this version:}

Camille Gardesse, Jodelle Zetlaoui-Leger. Citizen participation, an essential lever for urban transformation in France?. Localism and Neighbourhood Planning: Power to the People?, 2016. hal01884114

\section{HAL Id: hal-01884114 \\ https://hal.science/hal-01884114}

Submitted on 29 Sep 2018

HAL is a multi-disciplinary open access archive for the deposit and dissemination of scientific research documents, whether they are published or not. The documents may come from teaching and research institutions in France or abroad, or from public or private research centers.
L'archive ouverte pluridisciplinaire HAL, est destinée au dépôt et à la diffusion de documents scientifiques de niveau recherche, publiés ou non, émanant des établissements d'enseignement et de recherche français ou étrangers, des laboratoires publics ou privés. 


\section{Citizen participation, an essential lever for urban transformation in France?}

GARDESSE (Camille), ZETLAOUI-LEGER (Jodelle), "Citizen participation, an essential lever for urban transformation in France ?", in Quintin Bradley, Sue Brownill eds, in Neighbourhood Planning and Localism : Power to the People ? Policiy Press, Bristol, UK, 2016, pp. 199-214.

Planning in France has always been a state affair. In the 17th century a territorial administration was created to implement the rational organisation of space through centralised infrastructure as the cornerstone of the new-born nation state and, from the late 18th century, a vector for republican values (Foucault, 1975). In the late 20th century, despite a shift towards decentralisation that saw private actors taking a central role in urban planning, things remained fundamentally unchanged. By defining and implementing urban laws, including the process for the declaration of public utility, national and local government remain responsible for orchestrating spatial planning (1). This hierarchical system continues to deeply structure the mechanisms governing urban development despite the changing 'rules of the urban game' (Bourdin, et al 2006). According to professionals and researchers, the changes occurring include: the need for greater horizontal cooperation between all actors; the growing importance of public-private partnerships in project organisation and the necessary promotion of the principle of citizen participation in urban design and infrastructure projects. Another change underway is the fledgling role accorded to residents ${ }^{1}$ during specific phases of urban planning process phases. Without calling into question the fundamentals of representative democracy, where the final decision-making power is accorded to elected administrators, new political forms are emerging in which citizen participation is integrated into public action in the field of urban development.

These transformations call into question the French notion of l'intérêt collectif (the collective interest) that has its roots in the concept of l'intérêt général (the general interest). This relationship to the collective interest largely distinguishes French and Anglo-Saxon approaches to citizen participation in urban planning. The expression l'intérêt général is more generic and impersonal than l'intérêt collectif, a term derived from the substantialiste approach of the Jacobin state during the French Revolution and that better captures the notion of a group of individuals. In the 18th century the notion of the 'general interest' became current, replacing the 'common good' with its religious and moral connotations. For the following two centuries the legitimacy of state intervention was entirely based on this concept and in certain domains the only legitimate actors were public authorities. Yet as the nature of public action evolved, this vision of the state's role became increasingly contested and new regulatory modes emerged involving different types of actors, including members of civil society endowed with a certain form of legitimacy.

In France, the notion of 'the general interest' implies a stable condition defined by a centralised, devolved state or by its local representatives. In comparison, the Anglo-Saxon conception of 'the collective interest' is more related to the bien commun (common good), an expression whose etymology suggests negotiation, shared responsibilities and interdependence. This 'common good' is identified through debate and through the expression of different interests and points of view (Bacqué and Gauthier, 2011). In comparison, French public officials, elected by universal suffrage, consider themselves to be the custodians of the

\footnotetext{
${ }^{1}$ This term is used to designate all persons who feel concerned by the future of a place, whether they live or work there, or even maintain symbolic or emotional ties with the place.
} 
'general interest' (Rosanvallon, 2008). Intrinsically linked to republican ideals, these constitutive elements of the French nation state become apparent in different forms during urban and infrastructure projects.

In this way, a deep hierarchical gap has evolved between elected officials and their constituents, as well as between publicly mandated planning experts and residents. This gap reinforces the effects of the positiviste vision of the construction of scientific and technical knowledge. With its roots in the Enlightenment and consolidated through the prism of national histories, positivism spread throughout the world and across disciplines including that of urban planning (Allemendinger, 2002). In France, this led to the attribution of highly distinct roles for elected officials and residents in the production of the lived environment, de facto excluding 'ordinary citizens' from any possible recognition of political or technical competences and thus the capacity to act. The elitist exercise of power has contributed to a growing distrust between the elected and their electors, an issue at the heart of citizen participation policies of recent years.

Another principle at the heart of French political culture provides the key to understanding the attitude of elected officials and professionals towards citizen participation, and the approach to the democratisation of public action on a local level. This principle, considers citizenship as being based on equal rights and obligations in a republican system that does not recognize the idea of 'community', considered to potentially associate an ethnic or religious minority to a geographical space. These two principles have led to major differences between France and Anglo-Saxon countries where communautaire and 'empowerment' practices have structured social and urban policy for the last forty years, in particular in poor neighbourhoods (Bacqué et al, 2005). Despite these differences, the concepts 'common good' and capacitation citoyenne (the French version of the Anglo-Saxon term 'empowerment') have entered into the urban planning vocabulary in France since the end of the 2000s. Imported by associations working in underprivileged neighbourhoods and by citizen participation activists and researchers aware of international experiences, these terms have been slowly picked up by elected officials and planning professionals. How are these intentions expressed in the definition and implementation of urban projects? What are the challenges to citizen participation if it is to gain scope and momentum in France today?

In considering these questions, this chapter will situate the contemporary period within a broader, dynamic context of the evolution of resident involvement in urban planning in France. It argues that the history of French citizen participation since the 1960 s can be understood through three key periods that correspond to fundamental shifts in the attitudes of public authorities and citizen organisations towards its objectives and methods.

\section{Part 1: from 'urban struggle' to the attempted control by public authorities of resident participation}

The regulatory framework for citizen participation: concertation rather than 'participation'

As in many countries around the world at this time, the incursion by residents into French urban planning occurred in the 1960s and took the form of local protests to productivist economic objectives and to a rational global planning model. Against a backdrop of rapid urban growth and concern for egalitarian territorial treatment, the scope and urgency of postwar housing and infrastructure problems resulted in particularly centralised modes of 
planning and standardised constructions. Led by an alliance of the state, developers and architects, this approach tended to overlook local specificities, the history of places and the different ways in which existing spaces had been appropriated (Lefèbvre, 1966). In the 1970s Marxist sociologists labelled resistance to this model of urban design luttes urbaines (urban struggle), a movement essentially led in France by middle-class individuals belonging to either newly created 'revolutionary' groups or to more structured associations, unaligned to any political parties but in the tradition of left-wing or Christian activism through popular education (Castells, 1973).

These 'urban struggles' and other participative experiences carried out in the momentum of May 68 faltered and became rare in the 1980s. This period was marked by several new phenomena including the departure of the middle class from the popular neighbourhoods that had fostered these movements, the upward mobility of key association leaders who were drawn into the political sphere and the progressive implementation of a legal and institutional framework for resident participation that channelled it towards bodies with only limited power. In this slippage, the 'bottom-up' activist movement became a 'top-down' movement organised and normalised by the state through ambiguous structures created for mediation between associations and regulatory entities. An incentive-based legislation emerged in the domain of urban planning with the directive that citizens should be involved in every step of the development of projects concerning their living environment. In this framework, the creation of local democratic structures as well as mediation channels between institutional actors and members of civil society (such as conseils consultation locative, local housing, neighbourhood and development committees) were encouraged or made obligatory depending on the size of the town. During this period, while most countries used the term 'participation' to refer to resident involvement in public projects, in France, the term concertation was adopted. Far-left activists considered the term 'participation' to be a tool used by 'the dominant' over 'the dominated' and local and national political elites feared its potential as a counter-resistance instrument that would undermine their authority and revive social tensions. While they could not radically object to its underlying principles (for to do so would be contrary to the French Constitution) local officials argued for the creation of an administrative framework to structure residents' involvement in urban projects.

The term concertation has no direct equivalent in English and was preferred by French legislators in the drawing up of urban planning texts. Introduced within economic planning $a$ la française, the notion of concertation bears an institutional connotation. From the $1950 \mathrm{~s}$ it referred to a working relationship established between bureaucrats and key economic players to fix growth objectives, a term then broadened to include territorial and infrastructural development policy. From the 1970s onwards, concertation replaced 'participation' in the vocabulary of elected officials and development professionals, with a broader meaning that included dialogue with residents and, most of all, associations. This development was not innocuous for it expressed the public authorities' desire to organise and control forms of dialogue, as well as a preference for dealing with intermediary actors. It reflects a politicoadministrative culture anchored in a top-down vision of the organisation of state actions. However whereas concertation in its original vocabulary of economic planning referred to negotiations between stakeholders with a shared goal, this was not the case when residents were to be involved. Over the following years the term was gradually emptied of any substance in terms of both legislation and practice. In 1992 the French Conseil d'Etat (Council of State) decreed that, in reference to the urban code, the minimal and acceptable level for concertation was the publication of project information and the gathering of public commentary and observations. 


\section{Participative experiences limited in scope and visibility}

While the political and legislative context seemed favourable to the development of resident participation, no serious thought was given to the right to be informed and to participate; no concrete objectives were identified and there was no consideration of the means required to implement these rights (Blondiaux, 2005). Thus from the 1990s onwards, with due respect for their legal obligations, public project contractors did not hesitate to highlight the element of concertation in their operations. However at a closer inspection it quickly became apparent that the processes in question rarely went beyond a consultative phase (2).

To explain their reticence towards including residents at the early, diagnostic phase of urban projects, local authorities cited the fear of appearing before residents without the financial or technical guarantees to ensure a particular project or outcome. Urban project management methods also contributed to this reticence; technical managers, used to simply recording needs and formulating recommendations, dreaded facing endless, impossible requests from inhabitants and preferred to present them with already well-advanced projects. Furthermore, a high level of resident involvement was rarely considered important; in a fatalistic way, contractors would express regret over certain populations' lack of interest in urban projects, thus explaining the low diversity of participating groups. However in general, contractors were perfectly satisfied for their main interlocutor to be concerned resident associations as, though often vociferous and likely to slow down a project's advancement, they could be channelled and controlled. Finally, citizen concertation was generally perceived to be politically risky due to the level of transparency and debate required for it to be effective (Dimeglio and Zetlaoui-Léger, 2007; Gardesse 2011). With all of these factors combined, certain parts of the population - typically young, working class, underprivileged and recent immigrants - were the least represented and any concertation citoyenne occurred in a very closed circuit (Carrel, 2014).

From the 1980s, some more ambitious processes were nonetheless tried out, for example in the development of the 'generative programming' method concerning social housing rehabilitation and public facility projects, and based on a collaborative process between political, technical and civic bodies (Conan 1997 ; Zetlaoui-Léger 2015). In the 1990s, English agency John Thomson and Partners applied its urban planning approach to several French cities, in collaboration with French urban designer Eléonore Hauptmann. Despite the quality of the results obtained and the steps taken to sustain them, these experimental projects required difficult paradigm shifts and urban project management habits did not evolve much in France until the middle of the 2000s.

Added to this institutional reluctance, citizen mobilisation appeared to be difficult to muster, a situation further complicated by France's fundamental rejection of any form of communitarianism. In Anglo-Saxon countries, community planning techniques are based on the identification of shared-interest groups (age, profession, culture, leisure) and can also include other 'life communities' (ethnic or religious for example), with the involvement of these groups in the collective elaboration of projects. However, in France these practices are difficult to envisage for they refer to social groups who have no legal definition or rights, and it is easier to involve populations who are already involved in well-identified associative structures. The issue of the scope and representative nature of resident participation in France is often used to undermine its effectiveness. The problem is hard to resolve and citizen participation can be discouraged and even discredited by its excessive institutionalisation. 


\section{Part 2: from 2000, inhabitants' role in urban planning reconsidered?}

The preceding developments confirm the general perception of a highly bureaucratic French democracy. They also show how political initiatives to regulate resident involvement in urban development were more concerned by potential risk to the representative French democratic system than a real political desire to change the decision-making process. These initiatives did not convey any conviction about the renewal of political authority or the role and effect of citizen participation on the quality of decision-making. Nevertheless, change was occurring at the heart of the French administration. With a growing awareness that conflict was increasingly complicating the preparation of major projects, fostering public debate over major infrastructure and urban design projects became an "obligation for public action" (Bacqué, Gauthier, 2011). Centralised rules were no longer politically relevant or socially efficient, thereby opening the decision-making process to residents. The institutionalisation of resident participation in French urban projects, in the last quarter of the 20th century, could be seen as a response to what Pierre Müller called the "crisis in the French public policy model" (Müller, 1992), or, in other words, the operational failure of a certain number of fundamental principles, frameworks and tools. The change in attitude in the French state to resident participation in urban planning was also due to external pressure, in particular the growing concerns about sustainable development in the international community as announced by the International Conference on Environment and Development organized in Rio in 1992.

\section{The influence of environmental discourses}

With its global, holistic vision of local development issues (Berke, 2002) and of the interdependence between those who produce urban space and those who live in it, sustainable development originated a profound renewal of citizen participation approaches and the organisation of projects, in particular on a neighbourhood scale.

In the 1990s and against a backdrop of decentralisation, 'the neighbourhood' emerged as the pivotal entity for engaging local democratic renewal in France. Confronted with deep social crisis in the banlieues (underprivileged suburbs) the Politique de la Ville placed the neighbourhood at the centre of an urban policy aimed at renewing and anchoring citizenship in a territorial framework (Bacqué, Sintomer, 2005). From the mid 2000s, public authorities considered the neighbourhood as a pertinent and perfectly scaled lever for testing and disseminating new sustainable urban practices (3). The first ecodistrict projects raised pointed questions about the processes and reception of change in people's everyday habitat and habits.

With growing awareness about global environmental issues such as climate change or biodiversity conservation, sustainable development created a new roadmap with a discourse about the need to change living habits. Urban project managers now actively sought to accompany residents in these changes, contrary to their behaviour during the modernisation period in the 1950s and 1970s. In particular, communication with residents was greatly intensified during the first ecodistrict projects, with the aim of informing, explaining and encouraging 'more virtuous' living habits (according to expert definitions). These information channels are still the most frequent 'participative' modes adopted by urban project managers, their main objective generally being to establish that citizens' daily lives conform to standardised buildings designed to meet an idealized eco-resident typology (Renauld, 2014). However, ecodistrict projects were also a chance for almost a quarter of French local authorities to attempt more ambitious participative approaches, such as the collaborative design of partial or entire projects. These experiences were possible when urban contractors, 
in particular local authorities, closely linked environmental issues with socio-economic and political issues in a process of re-democratisation that transformed residents into active citizens.

In developing these actions and by observing how residents expressed their point of view on quality of life and urban use practices, it became clear that, instead of being occasionally consulted and/or generally dissociated from decision-making, residents needed to be integrated throughout the entire project process (Zetlaoui-Léger, Fenker, Gardesse, 2015).

\section{$\underline{\text { Political, cultural and professional codes under stress }}$}

In terms of the organisation of urban projects, the changes at Paris City Hall since the early 2000 s are an interesting reflection of the overall changes in the practice and representation of public action but also of how institutional inertia acts as a brake on citizen participation in France. For example, the organisation and implementation of the Paris Rive Gauche (13th arrondissement) and Pajol (18th arrondissement) in the mid 1990s, as well as the 2002 launch of the Les Halles forum and garden renovations, revealed changed attitudes by certain political and technical actors towards citizen concertation. These changes not only expressed the desire to break with previous ways of operating, they were also the result of committed resident groups who used concertation regulations to communicate their claims and propositions on the subject. While the movement was initially one of protest (against a lack of information about the City Hall's intentions and the fact that residents hadn't been seriously involved in the projects) it was accompanied by proposals for the neighbourhood's future as well as ideas about how to genuinely conduct a 'concerted' approach. These experiences were instructive for public authorities and professionals working on the projects (Schön, 1983) and as a result, training sessions were developed to encourage project leaders to change methods during these and future operations. Many public officials and urban professionals recognized the need for a collective cultural adaptation to citizen participation. They stopped invoking the often-impossible requirement that only residents with a full understanding of citizenship, architectural and urban regulatory codes could take part in participative urban projects. The City of Paris - as well as other cities such as Bordeaux and Strasbourg - today offers training and guidelines on this subject for political, technical and administrative staff to help them with their projects and practice. Several City Hall departments are now obliged to integrate participation into their actions. Participation is no longer systematically perceived as a communications process for convincing residents to adhere to a project envisioned by an elected official. Instead, it is now an indispensable mechanism in urban projects.

Despite these transformations, one cannot speak of a radical about-face in urban project practice and the local management of public affairs. Urban affairs in France are largely organised through a double-delegation power model that gives priority to technical thinking. On the one hand is the representative democratic system, considered to be the only legitimate political system; on the other hand is the designer-architect, considered to be the only legitimate author-creator. In preconfiguring the relationship between local urban authorities and citizen participation, these 'cultural codes' (Gardesse, 2011) structure its practice and outcomes (4) like a 'habitus' that plays a determining role in the definition of public territorial action. These cultural codes are particularly noticeable among the national deputies charged with redefining the Politique de la Ville plan for underprivileged urban zones. Noting that the concept of concertation had lost meaning over the years, the parliamentarians opted for the term 'co-construction', presented in the February 2014 law on Urban Cohesion and the City. 
But this concept was weakened through its attachment to the newly created administrative tools, the 'Citizen Committee' and 'Project House' to be implemented for each new urban project. Open to associations and to local actors, these instruments for concertation appear as the pillars of the renewal of democratic practice in the Politique de la Ville priority districts. They are the result of a report by academic Marie-Hélène Bacqué and association leader Mohammed Mechmache, conducted in 2013 at the request of the Ministry for Urban Affairs. In their report the authors recount the limited success of participative methods tried out in the underprivileged districts, all the while underlining the benefits of these actions for French society. The report's subtitle, "It can no longer be done without us" clearly illustrates the population's expectations yet the French parliament remains reluctant to adopt the report's principal recommendations such as financial support for residents' initiatives, or the independent review of projects in order to guarantee their neutrality. One of the fears raised by the report's propositions again concerns the emergence of religious or ethnic-based opposition groups.

Presented as a 'flexible' tool whose organisation is to be adapted to local situations, the Citizen Committee is the latest addition to numerous existing administrative structures linked to citizen participation and created within the Politique de la Ville urban and environmental regulatory codes. To be coherent and efficient, the Citizen Committee must respect certain criteria concerning skills and the role of experts, the parameters for action as well as the capacity to mobilise citizens. This new entity has also encountered problems concerning the selection of participating residents and/or their representatives. For example, in their report the two authors raise the issue of the right to vote for non-European residents as a prerequisite for the democratisation of public action in underprivileged districts, as promised by François Hollande during his 2012 presidential campaign. But the government refuses to implement this on the basis that to pass such a measure would require a two-thirds majority in both parliamentary houses, currently impossible to imagine. The implicit refusal to open a public debate on this question illustrates once again the lack of political conviction concerning the virtues of a genuinely deliberative procedure across local and national levels that associates elected political officers with ordinary citizens.

\section{$\underline{\text { Political action renewed by citizen activism }}$}

In reconsidering urban actors and decision-making processes through the lens of cultural codes, it is important to not freeze institutional actors into a fixed role. If the arrival of residents in the urban project 'arena' is considered by some to threaten the legitimacy of administrative actors, leading them to fall back defensively on cultural codes, this arrival is also clearly shaking up these same codes and rules. In the simultaneous movement of 'opening out' to resident participation while 'closing down' in defence, local authorities and urban professionals find themselves in a state of permanent tension. This tension can only be resolved by a new generation of political and professional actors, a point of view confirmed by the most ambitious participative experiences conducted in France over the last few years. The speed of these changes and their acceleration in certain administrations depends on the strength and nature of local democratic cultures, found in relationships built over the years between elected officials and local civil society. Through public debate and other forms of collaboration these relationships between political and associative leaders go beyond shortterm electoral stakes. They create the right conditions for participation whereby residents are not considered simple 'users' of urban territory but as citizens with the right to express their needs, opinions and propositions concerning the environment in which they live. Such is the 
case for cities such as Strasbourg and Grenoble. Following the 2008 municipal elections in Strasbourg, the newly elected officials announced their shared commitment with local associations to a new approach to urban planning. The new left-wing municipal authority could rely upon strong local associative networks to democratise public action. In Grenoble during the 1960s the associative movement was particularly strong in local politics, leading to the election in 1965 of one of their members, Hubert Dubedout, as city Mayor. In 2014, the city's residents once again elected a 'civilian' Mayor who, like his Strasbourg counterpart, built a political programme upon the two pillars of citizen participation and sustainable development. Today in Grenoble and Strasbourg, a new generation of urban actors is composed of local politicians and professionals who work in tandem and are involved in innovative participative schemes on a national level.

The institutionalisation of citizen participation in France in the 1980s did not herald the disappearance of spontaneous resident actions, even if at the beginning one of its major objectives was to limit such initiatives. Instead of being contained, these resident initiatives multiplied and diversified, going beyond protest to take on new forms, for example, the cohousing processes which in France today could lead to an important and necessary expansion of the country's housing stock. Going beyond the 1960s and 1970s utopian vision of communal living, the motivations guiding the people involved in these experiments are a pragmatic mix of the economic, social, environmental and political. These initiatives increasingly involve residents of all social origins who organise themselves into collectives and associations at a national level in order to share their experiences. For the last ten years, they have been putting pressure on public authorities on a local and ministerial level to gain support for their projects. In this way, both large and small city authorities as well as housing developers today support participative projects in their urban operations, considering them to be a new entry point to the housing market (Devaux, 2014) as well as a lever for raising the attractiveness of old and new districts. They count on the dynamism of committed local resident groups to develop the conviviality, solidarity and sense of communal well-being in their urban designs.

\section{Conclusion}

Until the 2000s the involvement of residents in urban planning in France, in terms of both conception and practice, was organised around two distinct rationales: the bottom-up 'urban struggles' of the 1960s and 1970s, then a series of regulatory and administrative provisions that aimed to provide a framework for citizen participation but ended up by circumscribing it. Recently, European directives linking sustainable development and citizen participation have strengthened regulations on participation and urban management. The last decade has thus witnessed a converging discourse between different administrative actors to defend the principle of urban 'co-construction' with the population. The two rationales that have for so long been opposed to one another - one of participation organized by public authorities but in fact seen by observers as undermining it; the other a spontaneous mobilisation often considered to be underlined by conservative aims - are evolving in their respective objectives and implementation methods and they are increasingly overlapping.

On an institutional level, the regulatory framework developed over the last thirty years was initially designed to defuse conflicts with civil society and avoid the blocking of projects. Today, a growing number of political and urbanism professionals admit that while conflict may be a regular project phase, it can only be surpassed if it occurs within a well-organised 
framework of debate that allows for the full expression of diverse points of view. Furthermore, citizen participation is increasingly associated with innovative practices in the domains of habitat, transport and social welfare. The resident collectives and local or global associations who mobilise around urban projects are increasingly considered not only as experts on the subject but as potential drivers for propositions about the design of sustainable districts and the fight against exclusion in underprivileged 'sensitive urban zones'. The virtues of 'community planning' tools have been (re)discovered by public authorities and urban professionals. Residents are getting organised at an early stage in urban development projects in order to have real impact on the improvement of their daily environment. Their actions are not necessarily oppositional; their protests are often accompanied by constructive proposals aimed at those public authorities ready to listen to and work with them (Gardesse, Grudet, 2015). Thanks to new communications possibilities, residents are able to build a shared culture around their participation practices that can also be developed and federated on a national level, often borrowing the language of urban ecology or underprivileged neighbourhood management to do so. Some groups aim for policy change on a local or national level, for example in the housing sector where residents contributed directly to the implementation of regulations encouraging different forms of participation.

Thus it would seem that France is undergoing a renewal of methods and expectations regarding resident participation. For pragmatic reasons, public officials and professionals in charge of implementing public policy are increasingly inclined to work with residents to ensure the relevance and feasibility of their projects. Given the issues at stake over the management of declining resources and the transition to renewable energy, the development of the social economy and the crisis in the traditional political model, there is a growing awareness that the spaces of our daily lives must be the product of cooperation between the different actors using and sharing them. Faced with the compartmentalisation of the public administration and its different technical divisions, residents' knowledge and input is crucial, especially given the recognised benefit of resident movements' actions for the bien commun territorial (common territorial good) (5). Although slightly unclear, this latter notion nonetheless allows urban planning professionals to develop a practice that closely links the concerns of living together, thinking together and acting together. This can encourage the development of citizen groups to define 'practice communities', without falling into communitarianism and the problem of minority rights.

While these reflections are today shared by diverse actors, the pervasiveness of certain cultural codes attached to both the framework of public action as well as the operational inertia of urban developers, limits the possibility of fully integrating them into the daily practice of urban design and land use planning. Despite a succession of grand speeches on the urgent necessity to reform and simplify the French administration, elected officials are hanging on to their often multiple political posts. The consequence is that the layers of territorial administration continue to overlap. This accumulation and entanglement only make governance more opaque, with long decision-making processes that can discourage citizen participation and weaken its impact. In parallel, the reduction in public finances along with the growing technical complexity of urban projects has led to an increasing trend over the last years to transfer urban project management to private operators. This often has the effect of disempowering public authorities and giving free reign to private actors in the definition of planning and construction programmes. Experience has shown that participative processes are difficult to maintain in a committed and long-term way with private developers who tend to be reluctant to involve residents, considering that such a process will hamper their work and objectives. Only strong local political willpower can create the conditions and support for 
ambitious, long-term citizen participation in France today. For this, local authorities also need the means to drive projects and work in partnership with developers and contractors in order to have an impact on outcomes. Many examples prove that local authorities, when renewed and jointly represented throughout all project phases by committed elected officials and ordinary citizens, are best placed to guarantee the 'common territorial good'. Put differently, to be effective, citizen participation still requires strong state leadership... perhaps another French exception?

\section{Acknowledgments}

The authors thank Sue Brownill and Quintin Bradley for their suggestions in the elaboration of this article, and Miranda Salt for her collaboration in the translation work.

\section{ENDNOTES}

1. Through the 'Code de l'Urbanisme' and the 'Code de l'Environnement'

2. During the first National Urban Renewal programme (2003-2013), successive annual evaluation reports show that, in general, residents were not involved in either the design or development stages of urban planning, housing and infrastructure projects.

3. Notably through regulatory incentives for local authorities to commit to ecoquartiers, or ecodistricts, implemented following the Grenelle Environmental Forum in 2007.

4. By 'culture' we refer to a structure that organises actions in function of contextualised political and social values as well as, in the domain of urbanism, a series of norms that allows different actors to recognise and be recognised as belonging to this field

5. À la recherche du bien commun territorial, Urbanisme, Hors Série n52, March 2015

\section{BIBLIOGRAPHY}

Bacqué, M-H., Sintomer Y, Rey, H. (eds) (2005), Gestion urbaine de proximité et démocratie participative, Paris, La Découverte.

Bacqué, M-H., Sintomer Y. (eds) (2011), La démocratie participative, histoire et généalogie, Paris, La Découverte

Bacqué M-H., Mechmache, M. (2013), Participation des habitants : le pouvoir d'agir des citoyens, rapport pour le Ministère de l'Égalité des Territoires et du Logement, juillet 2013, http://www.territoires.gouv.fr/spip.php?article3494

Bacqué M-H., Gauthier, M. (2011) 'Participation, urbanisme et études urbaines', in Participations 1/2011 ( $\mathrm{N}^{\circ}$ 1), pp. 36-66.

Berke, P., (2002), 'Does sustainable development offer a new direction for planning? Challenges for the Twenthy-first Century', in Journal of Planning Litterature, Vol. 17, $\mathrm{n}^{\circ} 1$, pp. 21-36

Blondiaux, L., (2005) 'L’idée de démocratie participative. Enjeux, impensés et questions récurrentes', in Bacqué, M-H., Sintomer Y. (eds), La démocratie participative, histoire et généalogie, Paris, La Découverte

Bourdin, A., Lefeuvre, M-P., Mele P., (eds) (2006), Les règles du jeu urbain - Entre le droit et la confiance, Paris, Descartes et compagnie

Carrel, M., (2014), Faire Participer les habitants? Citoyenneté et pouvoir d'agir dans les quartiers populaires, Paris, ENS Edition

Castells M., (1975), Luttes urbaines et pouvoir politique, Paris, Maspero 
Conan, M., (1997), L'invention des lieux. St-Maximin, Théétète

Devaux, C., (2014), L'habitat participatif, de l'initiative habitante à l'action publique, Rennes, Presses Universitaires de Rennes, 396 p.

Dimeglio, P., Zetlaoui-Léger, J., (2007) 'Les rapports ambigus entre politiques et citoyens : le cas du réaménagement du quartier des Halles à Paris' in French Politics, Culture \& Society, Vol. 25.2, New-York

Foucault, M., (1975), Surveiller et punir. Naissance de la prison, Paris, Gallimard

Gardesse, C., (2011), La "concertation" citoyenne dans le projet de réaménagement du quartier des Halles de Paris (2002-2010) : les formes de la démocratisation de l'action publique en urbanisme et ses obstacles, Thèse de 3e cycle en Urbanisme, Aménagement, Politiques Urbaines, Dir. Zetlaoui-Léger J., Lab'Urba - Université Paris Est

Gardesse, C., (2013), 'La double invisibilité des citoyens et de leurs expertises dans un dispositif participatif : le traitement de la dimension métropolitaine du site des Halles de Paris dans le projet de réaménagement du quartier, 2003 - 2010', in Hamman $\mathrm{Ph}$. (dir ${ }^{\circ}$ ) Ville, frontière, participation : de la visibilité des processus démocratiques dans la Cité, série « Des textes et des lieux », Strasbourg, Editions Orizons, collection Universités

Gardesse, C., Grudet, I. (2015), 'Continuités et discontinuités de l'implication des habitants dans les écoquartiers : le cas de la Zac Pajol à Paris', in Développement durable et territoires, https://developpementdurable.revues.org/10966

Müller P., (1992), 'Entre le local et l'Europe. La crise du modèle français des politiques publiques', in Revue Française de Science politique, 42-2

Renaud, V., (2014), Fabrication et usage des écoquartiers. Essai critique sur la généralisation de l'aménagement durable en France, Presses polytechniques et universitaires romandes.

Rosanvallon, P., (2008), La légitimité démocratique, les théories de l'intérêt général, Paris, Seuil.

Schön, D., (1983), The reflective practitioner, San Francisco (CA), Jossey-Bass Publishers, Wates, N., (1996) The Community planning handbook, London, Earthscan.

Zetlaoui-Léger, J., (2015), 'Invention et réinvention de la «programmation générative » des projets : une opportunité de collaboration entre architecture et SHS pour des modes d'habiter « durables »', in Revue CLARA, $n^{\circ} 3$, Université Libre de Bruxelles, pp. 101-114.

Zetlaoui-Léger, J., Fenker, M., Gardesse, C., (2015), 'La participation citoyenne dans les projets d'écoquartiers en France : quels "leviers d'expérimentation" ?', in Mermet, L., Salles, D., Environnement et transition écologique, Éditions De Boeck. 